\title{
A KERYGMATIC LITURGICAL MODEL OF CATECHESIS IN THE WORK OF SOFIA CAVALLETTI
}

MARIE Z I M M R M A N OVÁ

\section{ABSTRACT}

This paper presents a kerygmatic liturgical model of catechesis as a tool, which has its place especially in the Christian initiation of the children and adults. In the first part of this article we consider the purpose and meaning of the models of catechesis. It especially focuses on the results of the work of Josef Andreas Jungmann, who is the author of the concept of kerygmatic teaching in catechesis. In the second part we present the application of Jungmanns's approach to the Catechesis of the Good Shepherd program by Sofia Cavalletti and we point out the potential of this program for the renewal of catechesis of children in the Czech Republic.

Key words

Catechesis; Kerygmatic liturgical model; the Catechesis of the Good Shepherd; Christian initiation; Josef Andreas Jungmann; Sofia Cavalletti

DOI: $10.14712 / 23363398.2018 .50$

\section{A}

kerygmatic liturgical model of catechesis is a tool which has its place especially in the Christian initiation of the children and adults and which reflects on the current need by Pope Francis to return to kerygmatic and mystagogical catechesis. The purpose of this paper is to introduce the starting points of this kerygmatic liturgical model of catechesis according to Josef Adreas Jungmann, and to study its application in the theological concept of Sofia Cavalletti's work called the Catechesis of the Good Shepherd. 


\section{The Models of Catechesis - the Idea, Purpose and Meaning}

The term "models of catechesis" has appeared in the catechetics in connection with the effort of protagonists of the international catechetical movement at the renovation of catechesis in order to achive evangelization of the faithful. ${ }^{1}$ Article 9 of the General Catechetical Directory ${ }^{2}$ refers to this, but it does not use the term "catechetical models" ${ }^{3}$. Not even among the Czechs it is common to ponder on the model of catechesis while seeking suitable methods for a particular group of catechising people. The Czech professional journal Cesty katecheze presented some classic and newer models in 2010 based on the lecture of Cardinal Avery Dulles and the article of Belgian scientist André Fossión. ${ }^{4}$ Summary of these catechetical models can be also found, for example, in the work of Italian catechetics Flavio Placida in the publication Comunicare Gesü. This author uses, as a synonym for "model", the term "paradigm". It is a specific formula of thinking on how to look at the didactic approach to the catechesis. In this article, the theme will be our interest in "the kerygmatic liturgical model of catechesis". ${ }^{6}$

The knowledge and reflection of described models of catechesis are of considerable importance. They are specific tools, the choice of which allows us to respond to the specific needs when presenting the Gospel message in the catechesis according to the request of the General Catechetical Directory (GCD) and the General Directory for the Catechesis $(\text { GDC })^{7}$. The choice of the suitable model of catechesis depends on the tasks of the catechesis (GDC 84-85). It is not possible to complete all

1 The Catechetical Movement reached its conclusions during the international catechetical study weeks held in the 1960s gradually in all continents. Cf. Michael Warren. Sourcebook for Modern Catechetics. Winona, Minnesota: Saint Mary's Press 1983, pp. 23-65.

2 The General Catechetical Directory. Roma: Libreria Editrice Vaticana 1971.

3 The catechesis models are mentioned in Article 59 of the General Directory of the Catechesis (1997) in relation to the catechumenate catechetical model.

4 Marie Zimmermannová. Modely katecheze v historii i aktuálně. Cesty katecheze 2, 4 (2010), pp. 20-23; Fossión. Katechumenát jako inspirativní model každé katecheze. Cesty katecheze 2, 2 (2010), pp. 23-25.

5 Flavio Placida. Comunicare Gesù. La catechesi oggi. Città del Vaticano: Urbaniana University Press 2015.

${ }_{6} \quad$ There is a connection with the kerygmatic liturgical theology: Cf. Anthony Rosselli. Kerygma and the Liturgy: Encountering the Risen Christ in Dom Odo Casel's Mystery Theology. University of Dayton, 2015. [30. 1. 2018] http://rave.ohiolink.edu/etdc /view?acc_num=dayton1438425904.

7 GCD, art. $\overline{3} 7-46$ seeks to find ways to mediate the content of catechesis with regard to different forms of ecclesial life, diverse cultures, and different ways of expressing 
the tasks in a particular catechetical programme. For this reason, the catechist has to focus on some areas of the Christian life with respect to the participants and the purpose of the programme. The choice of the model of catechesis has an important place in this process.

\section{The Kerygmatic Liturgical Model of Catechesis according to Josef Andreas Jungmann}

The beginnings of the kerygmatic liturgical model of catechesis can be found in the works of the Austrian Jesuit Josef Andreas Jungmann (1889-1975). ${ }^{8}$ He split his working life into two fields: history and pastoral theology. During the Second World War, he focused his attention on studying the development of the Christian tradition. He is the author of the admirable work Missarum Sollemnia. ${ }^{9}$ He saw the meaning of his work in assisting the theology to become more open to the development and to discover its more profound roots. ${ }^{10}$

In the field of pastoral theology, Jungmann directed all his work towards expressing his vision of education as preaching and catechesis, which answers the needs of ordinary people wanting to live their faith intelligibly and in compliance with their intuitive thinking. ${ }^{11}$ He was convinced that Christian faith does not need to be perceived as opaque and complicated. He suggested that it is inappropriate to present the scholastic theology to faithful because it is not suitable for nourishing their faith. It had to be replaced by kerygma with a clear presentation of the core of the Christian faith. He emphasized the value of the historical and narrative approach to catechesis rather than an abstract and philosophical approach. ${ }^{12}$ Jungmann introduced his

people. The GDC deals with these issues in Chapter 1 of II. a section entitled "The Gospel Message", i.e., in art. 94-118.

8 For basic information see: Marie Zimmermannová. J. A. Jungmann a kérygmatický př́stup ke katechezi. Cesty katecheze 3, 1 (2011), pp. 20-21. Cf. Timothy O'Malley. The Kerygmatic Function of Liturgical Prayer: Liturgical Reform, Meaning and Identity Formation in the Work of Josef Jungmann SJ. Studia Liturgica 41, 1 (2011), pp. 68-71.

9 Josef Andreas Jungmann. Missarum Sollemnia. Eine genetische Erklärung der römischen Messe. 2 voll., 5th ed. Bonn: Nova \& Vetera, 1962.

10 Cf. Michael Warren. Jungmann and the Kerygmatic Theology Controversy. In idem. Sourcebook for Modern Catechetics, pp. 193-199.

11 It is about "the supernatural appreciation of faith on the part of the whole people" according to Lumen Gentium, art. 12. Jungmann shared this approach with his colleagues, brothers Rahner, at the Theological Faculty of Innsbruck.

12 Cf. Warren. Jungmann and the Kerygmatic Theology Controversy, p. 194. 
approach for the renewal of catechesis of children and sermons for adults for the first time in 1936 in the work Die Frohbotschaft und unsere Glaubensverkündigung. ${ }^{13}$

Jungmann's interest in liturgical theology and his efforts in proclamation of the Gospel as a Joyous Message is the basis for the creation of the Kerygmatic-liturgical model of catechesis. According to Jungmann's article on kerygmatic education published in the journal Lumen Vitae in $1950^{14}$, this model makes use of these points:

1. There are problems with Christian faith in the countries where religious education in schools has a traditional form, and where pupils are taught more theology than a medieval priest. Most people know all the sacraments and something about Jesus, the Virgin Mary, the apostles Peter and Paul, Adam and Eve, and many more, but they have no sense for unity, cannot see the whole picture, and understanding the admirable message of God's love.

2. One of the key points of catechesis is the relation between the doctrine and the mystery. The degradation of God's mystery only to doctrine, to make it be comprehensible for human intellect, is the source of the heresies. The lack of understanding and loss of the connection with life of the people is the consequence of the degradation of God's mystery to a subject of examination, definitions, etc. It is necessary to develop a new useful concept for a better understanding of the truth. The presentation of the Christian mystery must be coherent and unified. It is necessary to prefer the narrative and historical approach and to find inspiration in the mystagogical method of the Church Fathers in the catechesis.

3. "How can we arrive at the knowledge of God?" It is necessary to point at the centre and the rays, which radiate from this centre and shine on the whole thing. This centre can only be Jesus Christ, our Lord. He illuminates all our knowledge of God, man and the world. We must get to know Christ in the light of his mission. The Church should appear as the fruit and continuation of his work.

4. It is not acceptable for religious instruction when: the catechism makes the impression that Christianity is a set of theses, to which one

13 Josef Andreas Jungmann. Die Frohbotschaft und unsere Glaubensverkündigung. Ratisbona: Pustet 1936.

14 Cf. Josef Andreas Jungmann. Theology and Kerygmatic Teaching. In: Michael Warren. Sourcebook for Modern Catechetics, pp. 213-218, repr. from Lumen Vitae 5 (1950), pp. 258-263. 
must assent by one's faith; it is not brought out of the Church's fundamental structure, the community of those who are sanctified in Christ; God's love is not presented unconditionally. Kerygmatic teachings require more than a very clear exposition of doctrinal truths and more than their application to life in the manner of a technical school. The doctrine itself must be transformed by its incorporation into the whole of the Good News and adapted to its nature. The teaching of the Christian doctrine will then again emphasize the Good News, the invitation to the Kingdom of Heaven! The response will be a joyful echo in the heart. The fundamentals of the moral life should be shown in a joyful spirit as an answer to God's calling.

5. Since the middle of the sixteenth century, our textbooks of religious instruction have followed the analytic method. Today, however, Christians need to see the whole plan of salvation and to shape their lives as part of this plan. It is necessary to present the whole vision as a vast panorama. All people and each individual should be provided with the knowledge of God's plan. We enter with Christ and through him the house of the Father! This message must be shown in the context of God's plan, which the child should never forget.

6. Baptized children, who are already in the Kingdom of God, need to be made conscious of what they are and what they must remain. They should be initiated into the life based on Christian faith. They should be shown that there is a treasure for which it is worthwhile to sell everything in order to get it.

7. Grace and the sacraments must be taken out of their isolation; thus the mistake of taking them for just "things" can be avoided. They cannot be connected only with morality because they can be useful in the observance of the Commandments. We must understand their connection with the recognition of Christ and the Church and how it is indicated in the Creed.

Josef Andreas Jungmann took part in the preparatory commission of the Second Vatican Council, which published the documents for the kerygmatic approach in theology. We have on mind especially articles 2-5 in the constitution Lumen Gentium about the Church. Articles 1012, 21 and 44 in the GCD and articles 97-107 in the GDC correspond with the aforementioned constitution.

Pope Francis confirmed the correctness and the timelessness of Jungmann's intuition and vision in the adhortation Evangelii gaudi$u m$ in the part called "Evangelization and the deeper understanding of 
the kerygma" (art. 160-166). The Pope reminds us of the central role of kerygma in the renewal of the catechesis and the role of mystagogical catechesis, which are to support "a progressive experience of formation involving the entire community and a renewed appreciation of the liturgical signs of Christian initiation." ${ }^{15}$

\section{Sofia Cavalletti and Her Work for Catechesis}

Sofia Cavalletti was an Italian theologist. She studied Hebrew, biblical sciences, and later liturgical theology. She was a member of the Centro Pro Unione and the "Service de Documentation Judéo-Chrétienne" (SIDIC), that was set up after the publication of the Council Declaration Nostra Aetate for Jewish-Christian relations. ${ }^{16}$ Since 1954, Cavalletti and her fellow worker Giana Gobbi have developed a program called the Catechesis of the Good Shepherd (CGS), which was based on the work of Maria Montessori. The circumstances of the development of this program, and in particular its principles, content and method, are described in several seminal publications from which we will draw. ${ }^{17}$ The CGS was modified during its sixty years of existence based on observations of children during their work, the study of children's verbal and artistic expression, and reactions of children to particular themes and activities. ${ }^{18}$ Today the CGS is now found in dozens of countries in all continents and interest in it has been rising. ${ }^{19}$ Since 2011, the priests, catechists, and parents have become aware of the CGS in the Czech Republic. ${ }^{20}$

15 For more details, see Placida. Communicare Gesù, pp. 171-176.

16 Mary Mirrione. Sofia Cavalletti 1917-2011. The Sower 3 (2012), pp. 5-9.

17 Scottie May. Sofia Cavalletti in Christian educators of the 20th century. https://www .biola.edu/talbot/ce20/database/sofia-cavalletti [30. 1. 2018]; Sofia Cavalletti. Potenziale religioso del bambino: descrizione di un'esperienza con bambini da 3 a 6 anni. Roma: Città Nuova 1979 (transl. The Religious Potential of the Child. New York: Paulist Press 1992; =Religious Potential I); eadem. Potenziale religioso tra i 6 e i 12 anni: descrizione di un'esperienza. Roma: Città Nuova 1996 (transl. The Religious Potential of the Child 6 to 12 Years Old: A description of an experience. Oak Park, IL: Catechesis of the Good Shepherd Publications 2002; =Religious Potential I); eadem. La storia della salvezza: dalla creazione alla redenzione. Roma: Coletti 1999; eadem. Liturgia vivente, riflessioni elementari, 1998 (transl. Living liturgy: Elementary relfections. Oak Park, IL: Catechesis of the Good Shepherd Publications 1998). Cf. Cavalletti. Religious Potential II, pp. viii-ix. ching young people the faith. https://www.americamagazine.org/issue/667/article /faith-child [30. 1. 2018]. .katechezedobrehopastyre.cz [30. 1. 2018]. 


\section{The Kerygmatic Liturgical Model in the Catechesis of the Good Shepherd Program}

The CGS program is for children aged 3 to 12, who are gradually introduced into the mysteries of faith and Christian life. The program is divided into three levels. Each level involves a three-year period in the life of a child. The content and methods of the CGS respect the physical, psychological, and spiritual specifics of the children in the corresponding period. ${ }^{21}$

The purpose of this part of the article is to look at the CGS program from the perspective of Jungmann's recommendations and criticism of catechesis, and to present it as an example of the realization of the kerygmatic-liturgical model of catechesis:

ad 1) The environment suitable for catechesis, the approach to catechesis, the seeing of the whole, the sense of unity, kerygma

Sofia Cavalletti as a child did not attend religious instruction at school because she came from a noble family, and was educated by home teachers. She established an atrium in her house for the children entrusted to her to be educated in the faith. This atrium incorporated three connected rooms for three age groups of children. The word atrium originates from the classical era, where it designated the vestibule for catechumens. This was where the first catechesis took place. In the CGS, the Atrium provides both the place for conducting catechesis and the community. In this community, the adults and children recognize God and experience meeting him and connecting with Him..$^{22}$ Atrium is a prepared environment to develop and nourish the Christian faith of children and adults. The child can work in silence and at his or her pace. Preserving the silence in the atrium allows children to meet an internal teacher. The role of a catechist is to provide fellowship for the child and to become its older brother or sister in the faith. ${ }^{23}$ The catechesis in the CGS program has all the attributes of an education in the

\footnotetext{
21 The access to the child and his belief in the CGS is presented by Giana Gobbi. Listening to God with Children. The Montessori Method Applied to the Catechesis of Children. Loveland, OH: Treehaus Communications 1998.

22 The Spirit of the Catechesis: 32 Points of Reflection, points 3 and 4. In: Cavalletti. Religious Potential II, pp. 133-134.

23 Cf. May. Sofia Cavalletti, p. 5.
} 
faith and contains all its components: meeting, teaching, contemplation, sharing, prayer and instruction for the celebrating.

The catechists introduce children to the core of Christian faith. According to Josef A. Jungmann, they proclaim "kerygma", which is the reference point for every truth of the faith. Kerygma has a unifying function for the content of catechesis. At first, the children recognize Jesus Christ in his connection with his Father and with us as it is based on the Holy Bible (during historical events such as his incarnation or the Easter event), the celebration of liturgy, and their own experience. ${ }^{24}$ Children learn to perceive God as a being who acts first, his words and deeds are in unity. At pre-school age, children's attention focuses on God's loving behaviour, and in school age they explore other people's activities and attitudes, and learn to recognise and respond to God's love in their lives. ${ }^{25}$

\section{ad 2) The relation between the doctrine and the mystery}

Religious education, and the focus on the aims and the knowledge, may lose sight of its missionary and ancillary character in the religious life of children. Cavalletti understood catechesis as a meeting with God's mystery, which leads children to contemplation and bears fruit such as: a sense of duty, a quiet joy, the recognition of truth in biblical and liturgical presentations, and the ability to express a clear insight into God's mystery in their drawings. ${ }^{26}$

Cavalletti described the method of the CGS as follows: "The Mystery is unfathomable, and there are many ways one draws near to it. It can be hidden in parables; it can be progressively manifested in the events of history; it can be celebrated in the liturgy. Yet, the method for attempting to penetrate the Mystery is always the same. It is that method that begins with concrete, perceivable elements that then point us to and help us live a reality that transcends those very elements. It is that method which opens up the whole of reality for us and enables us to see with new eyes its multiple levels of meaning. God uses this method in all his interactions with humankind, beginning with the creation of the world and reaching its highest expression in the incarnation of Jesus Christ."27

24 Cf. Cavalletti. Religious Potential I, pp. 4-5.

25 Cf. Cavalletti. Religious Potential II, pp. viii-xiv.

26 Cf. Foreword of Mark Searle in Cavalletti. Religious Potential I, pp. 3-4.

27 Cf. Cavalletti. Religious Potential II, p. 47. 


\section{ad 3) Jesus and the Church}

The CGS program is Christocentric, based on the reality of incarnation of the second divine person and its role as the Mediator between God and Man (John 14:6). ${ }^{28}$ The person of Jesus Christ and his mission is represented in two ways: historical and mystagogical, which complement each other. The historical way proclaims the history of Jesus' life from birth, resurrection to Parousia. Mystagogical way introduces children to the mystery of Christ, and his relationship with us based on the parables and images of the Gospel. In both ways, the children are gradually introduced to the purpose of existence and the sense of mystery of the Church that continues in Jesus' activities. ${ }^{29}$

Cavalletti presents the incarnation, death and resurrection of Jesus to preschool children as a great gift from God and the manifestation of His love; to the children of school age, in the context of God's plan of salvation, as a stage of redemption that culminates in the salvation history, and whose completion will be at Parousia. ${ }^{30}$ From the prophecies of the coming of the Messiah and from the story of Jesus' childhood, even small children recognize who Jesus is: a human child, because his mother is Mary, and the Son of God, too, because of unique signs from God accompanying his birth. ${ }^{31}$ Older children learn to perceive the meaning of Jesus' life in the context of God's plan of salvation and distinguish the vocation of Mary and Joseph to participate in God's plan by engaging in events when Jesus came into the world. This is an anthropological approach to catechesis. ${ }^{32}$ In the presentation of the Easter event as one whole, death and resurrection are always associated. These are the two sides of a single act of Jesus, whose fruits are gifts of a new life for his sheep. The empty grave is presented to children in separate catechesis as a sign of resurrection. ${ }^{33}$

The children penetrate into the mystery of Jesus on the basis of the parable of a good shepherd. On the first level of the CGS program, this parable presents the centre of catechesis, and all the other themes relate to it. Children know that the shepherd knows his sheep by name,

\footnotetext{
Cf. GDC, art. 99-100; It is the so-called Trinitarian Christo-centrism.

Cf. Cavalletti. Religious Potential I, p. 62.

30 For both reasons Christ's incarnation is expressed by Ctirad V. Pospíšil. Ježišz Nazareta, Pán a Spasitel. Praha - Kostelní Vydří: Krystal OP - Karmelitánské nakladatelství 2010, pp. 200-202.

31 Cf. Cavalletti. Religious Potential I, pp. 108-109.

32 Cf. Cavalletti. Religious Potential II, pp. $27 \mathrm{ff}$.

33 Cf. Cavalletti. Religious Potential I, pp. 115-116.
} 
calls them, leads them to pasture, walks in front of them, protects them against the wolf, seeks lost sheep, and gives his life for his sheep on the cross and in the Eucharist. This approach corresponds to thechild's need to be loved and protected. Children form a bond of trust with Jesus; they are attracted to their shepherds, for he knows what their sheep need. ${ }^{34}$

For school-age children, Cavalletti presents a meditation on the grapevine metaphor, which is a magnificent picture of the covenant based on communion and the intimate bond between Jesus Christ and us. Emphasis is placed on the requirement to "remain" in connection with Jesus so that our life can bring abundant fruits. Children are sensitive to the depth of this image and the mystery it shows, especially during the preparation for the first Holy Communion. This picture also prepares children to contemplate the mystery of the Church as the mystical body of Christ. ${ }^{35}$

ad 4) The proclamation of the Gospel as the Good News, the invitation into the Kingdom of God

What is the Good Message for the children? In general, we can say, the one that responds to their needs. The authors of the CGS program are patterned on three basic spiritual needs of children: 1 . the need to love and to be loved, which fulfils the parable of a good shepherd; 2 . the need to know the mystery of life, which fulfils the proclamation of the mystery of God's kingdom; 3. the need to penetrate the mystery of time that is related to God's plan of salvation. Satisfying these needs brings joy to children.

Jesus taught in parables about the important mysteries of the relationship between God and men and about the mysteries of our lives (Mt 13:34b-35). Jesus presented to his disciples the plan of his Father, especially in the parables of the Kingdom of God, often with great urgency (cf. Mt 6:33). Cavalletti chose for children of pre-school age a parable about the mystery of life and its enormous potential that God puts in as little things as the mustard seed (the smallest of all seeds), the yeast in the dough, and the grain seed that grows alone (Mt 13:33; Mk 4:26-29). While in earthly reality the Kingdom of God may seem infinitesimally small, it will be a huge tree at the end of time, it will encompass the

34 Cf. Cavalletti. Religious Potential I, pp. 62-77.

35 Cf. Cavalletti. Religious Potential II, pp. 53-57. 
whole world and bring abundant bounty. With the growing knowledge of the children, their wonder and understanding of this mystery deepens. The children gradually recognize the scope of God's actions: from the gift, they received in the baptism for their inner life, to the transformation of society towards social justice, freedom and peace. ${ }^{36}$

The parables of the merchants and pearls (Mt 13:45-46) and a man and the treasure in the field (Mt 13:44) are taught to educate people on the preciousness of the Kingdom of God. ${ }^{37}$ Children aged 6 to 9 already have new questions, asking for the beginning and the end of the Kingdom of God. The words of the prophets about God's plan (Is 40:3-5), about the coming of Jesus Christ in history (Is 11:1-3) and about Parousia (Is 11:6-9), help the children to find the answers they seek. ${ }^{38}$

The secret of the Kingdom of God is also associated with the Mountain Sermon, which contains challenges for Christian life. The children thus recognize that they are invited to receive the Kingdom of God by listening to the Word of God (through the parable of the Sower) and to spreading the Kingdom of God. ${ }^{39}$

ad 5) The vision of the Christian life in the context of the Divine plan of salvation

After sixth year, the child's interest in the past awakens and the need to penetrate the secrets of time grows. The child is looking for the answer to "What time is it?" We can do this by telling history. Cavalletti considers "How can we attend to the telling of history so that the magnificence of the mystery of time is not reduced to mere chronology?" The answer lies with a Greek historian from the 3rd century: Only through a unified vision will we achieve what is useful and precious. ${ }^{40}$

The grandiose plan of God with humankind is presented to the children through several aids that show history as a whole with three important moments: creation, redemption (the work of Jesus Christ continuing in his church), and Parousia. Three didactic aids are used in the catechesis: 1. the timeline strip (Fettucia); 2. the blue strip of unity of history; 3 . the strip of gifts. Marie Montessori prepared the first aid. It clearly connects the three moments in the History of salvation

\footnotetext{
Cf. Cavalletti. Religious Potential I, pp. 140-145.

Cf. ibid., pp. 145-147.

For more details see Cavalletti. Religious Potential II, pp. 1-10.

Cf. Cavalletti. Religious Potential II, pp. 88-89.

40 Cf. ibid., p. 15.
} 
with the knowledge of the history of the world. The second aid shows the evolution of the world in the context of the History of salvation in which God is constantly present, and the place of man in it: people will see the plan of God gradually as a river of time into which they enter and become part of this plan. The third aid enables children to view history as a wonderful overview of the gifts God has given to people. God is presented here as the God of the covenant, which lies in the relationship with the people that God initiates and awaits our response: at first admiration and acceptance, later our deeds. ${ }^{41}$

ad 6) Character of initiation and moral education in the CGS program

The character of the initiation catechesis ${ }^{42}$ requires the application of the kerygmatic-liturgical model of catechesis (celebration and testimony) combined with the anthropological model (specific manifestations of the Christian life). One of the goals of the CGS program is to teach children to nourish their life from the living resources of the faith, i.e., from the Scriptures and the liturgy. Cavalletti wrote about their complementarity: "One cannot be truly initiated to the Bible without also becoming aware of how it has been lived through the centuries. Among the various instruments of tradition, the liturgy is perhaps the most direct reflection of the life of believers... The Bible and tradition - and with tradition, the liturgy - must be considered as one entity. Only if the two are considered together, as making up a single whole, can they fully express their rich, life-giving potential. What the Bible and tradition proclaim needs to be completed through celebration." ${ }^{43}$ In theology, the Bible and the liturgy express the same core of the relation between God and man: it is the covenant; the Eucharist is the sacrament of the new and eternal covenant.

One is to seek the answer to the love God shows us through his covenant. This is one of the foundations of moral education. The second is the order we find in the creation we are a part of. Moral life is presented as a journey full of joy, which leads to a much richer life. Already at preschool age, children are regularly invited to respond spontaneously to the proclaimed Gospel in prayer. In the school age, they are presented with a parable of prayer, helping their neighbours, forgiveness, and

\footnotetext{
Cavalletti. Religious Potential II, pp. 29-31.

Cf. GDC, art. 65-68.

Cavalletti. Religious Potential II, p. 60.
} 
eschatological parables about the expectation of the second coming of Jesus Christ. The children meditate on them and seek their answers to the manifestations of God's love. They also use selected statements from the Mountain Sermon, the so-called maxims, in which they seek a connection with the parables that illuminate them. In her publications, Cavalletti provides a number of examples of the abilities of children to understand the depths of individual topics and how they relate to one another. $^{44}$

\section{ad 7) The sacraments as the meeting with Jesus Christ in the Easter event}

The introduction of the relationship between the Bible and the liturgy and the teaching of the liturgical language of the "sign", is the foundation for raising children to participate actively in the celebration of the sacraments. Children are introduced to the mystery of Baptism through exploration of the main sign of the children's baptism ceremony. The two signs are the light of the baptism candle and the white cloth as gifts of the light of the resurrected Christ, who overwhelmed the darkness; the actions of the Holy Spirit through the water and the Holy Scripture, which bring new life; the gestures of blessing the water and the sign of the cross on the forehead of the child point to the connection with the community of baptized gathered around a good shepherd. ${ }^{45}$

Cavalletti introduces children to the mystery of the celebration of the Eucharist in two ways (similar to the mystery of Jesus Christ). The first is historical: during Easter, the catechist presents to the children the last supper of Jesus with the Apostles. The event of the sending of the Holy Spirit takes place at the Cenacle, too. Children celebrate and meditate on the greatness of God's love, which includes many gifts. Later the catechist presents the catechesis about the origin of the Holy Mass and the spreading of the Church. ${ }^{46}$ During this catechesis, the Cenacle is transformed into a church by a simple exchange of a Jewish star for a cross with a glorified Jesus. Children will get the i.e., of the connection between Jesus, the bishop, the priests, and other believers. The second path is mystagogical: first, children are introduced to the image of the sheep gathered around the altar. Children already understand that sheep are human beings, and Jesus is not present at the altar as

${ }^{44}$ Cf. ibid., p. 84-104.

45 Cf. Cavalletti. Religious Potential I, pp. 94-105.

46 Cf. ibid., pp. 94-105. 
a shepherd, but they know it in the ways of bread and wine through the connection with the words of Jesus made at the Last Supper. The Good Shepherd who feeds his sheep and gives his life for them becomes real in the form of the Bread of Life, i.e., the Eucharist. ${ }^{47}$ The preparation for the Sacrament of Reconciliation and the First Holy Communion makes use of the grapevine metaphor, as mentioned above. ${ }^{48}$

\section{Conclusion}

The Good Shepherd Catechesis program responds to all the requirements of Joseph A. Jungmann for the renewal of the initiation catechesis. Its method can be understood as the realization of the kerygmatic liturgical model in catechesis. During recent years, there has been a greater interest in the CGS program, especially in Europe, including the Czech Republic and Slovakia, where the number of courses for catechists and participating parents is increasing. The effects of the program on children, catechists and parents and other areas of parish pastoral activities are very apparent, as Jungmann has already anticipated. Approaches and principles of the CGS program can be applied, for example, in initiation catechesis with adult baptism candidates or confirmands. They are also inspirational for catechists who describe their experience with the CGS program as "spiritual revival" and who have found "that which they were seeking their whole life". Application of the CGS program in pastoral practice points to the potential, timeliness, and viability of the kerygmatic-liturgical model of catechesis for the development of New evangelization.

Translated by Jakub František Vinklárek

Catholic Theological Faculty, Charles University

Thákurova 3

16000 Praha 6 - Dejvice

E-mail: marie.zimmermannova@ktf.cuni.cz

${ }^{47}$ Cf. Cavalletti. Religious Potential I, pp. 79-97.

48 Cf. Cavalletti. Religious Potential II, pp. 113-122. 